Article

\title{
Association of Twelve Candidate Gene Polymorphisms with the Intramuscular Fat Content and Average Backfat Thickness of Chinese Suhuai Pigs
}

\author{
Binbin Wang ${ }^{1,2}$, Pinghua Li ${ }^{1,2, *}$, Wuduo Zhou ${ }^{1}$, Chen Gao ${ }^{1,2}$, Hang Liu ${ }^{1,2}$, Huixia Li ${ }^{1}$, \\ Peipei Niu ${ }^{2}$, Zongping Zhang ${ }^{2}$, Qiang $\mathrm{Li}^{3}$, Juan Zhou ${ }^{3}$ and Ruihua Huang ${ }^{1,2, *(D)}$ \\ 1 Institute of Swine Science, Nanjing Agricultural University, Nanjing 210095, China; \\ 2018205003@njau.edu.cn (B.W.); zhouwuduo@njau.edu.cn (W.Z.); GC1594140795@126.com (C.G.); \\ lhomme@126.com (H.L.); lihuixia@njau.edu.cn (H.L.) \\ 2 Huaian Academy, Nanjing Agricultural University, Huaian 223005, China; niupeipei2@126.com (P.N.); \\ zongpingzhang@126.com (Z.Z.) \\ 3 Huaiyin Pig Breeding Farm of Huaian City, Huaian 223322, China; 13912078083@139.com (Q.L.); \\ 15261762741@163.com (J.Z.) \\ * Correspondence: lipinghua718@njau.edu.cn (P.L.); rhhuang@njau.edu.cn (R.H.)
}

Received: 2 September 2019; Accepted: 21 October 2019; Published: 23 October 2019

Simple Summary: Appropriate intramuscular fat content (IFC) is the goal of consumers and the direction that breeders must pursue. However, it is difficult to improve the IFC but not average backfat thickness (ABT) by traditional breeding methods, and pigs must be slaughtered to accurately measure IFC. Marker-assisted selection (MAS) provides an economic and efficient method to improve the IFC in pigs. Our research indicated that the FABP3 (rs1110770079) single nucleotide polymorphism (SNP) could be a candidate gene associated with IFC (but not ABT), and IFC could be improved by selecting the individuals with a favorable genotype (GG) of FABP3 (rs1110770079) SNP for pig breeding.

\begin{abstract}
The present study aimed to identify the molecular markers for genes that influence intramuscular fat content (IFC), but not average backfat thickness (ABT). A total of 330 Suhuai pigs were slaughtered, and measurements of IFC and ABT were obtained. Phenotypic and genetic correlations between IFC and ABT were calculated. Thirteen single nucleotide polymorphisms (SNPs) among 12 candidate genes for IFC were analyzed, including FABP3, LIPE, IGF1, IGF2, LEP, LEPR, MC4R, PHKG1, RETN, RYR1, SCD, and UBE3C. Associations of the evaluated SNPs with IFCIFC and ABT were performed. Our results showed that the means of IFC and ABT were $1.99 \pm 0.03 \%$ and $26.68 \pm 0.28 \mathrm{~mm}$, respectively. The coefficients of variation (CVs) of IFC and ABT were $31.21 \%$ and $19.36 \%$, respectively. The phenotypic and genetic correlations between IFC and ABT were moderate. Only the FABP3 (rs1110770079) was associated with IFC $(p<0.05)$ but not with ABT. Besides, there was a tendency for associations of RYR1 (rs344435545) and SCD (rs80912566) with IFC $(p<0.1)$. Our results indicated that the $F A B P 3$ (rs1110770079) SNP could be used as a marker to improve IFC without changing ABT in the Suhuai pig breeding system.
\end{abstract}

Keywords: Suhuai pig; intramuscular fat content; average backfat thickness; candidate gene 


\section{Introduction}

Meat is widely consumed as an important protein source for humans; pork occupies a dominant position in the consumption structure of meat in China [1], and its consumption is about $40 \mathrm{~kg}$ per person per year in recent years. During the past decades, breeders have mainly focused on the increase of growth rate, muscle deposition, and lean meat yield, resulting in a reduction in meat quality and fat deposition [2,3]. Intramuscular fat content (IFC) is a key indicator of the meat quality assessment system. Previous studies have indicated that IFC is closely related to flavor, juiciness, tenderness, and water-holding capacity [4,5]. IFC refers to the amount of fat accumulated between muscle fibers or within muscle cells, which could be extracted from muscle samples by using chemical methods [6]. The main components of IFC include phospholipids and triglycerides [7]. Recently, some studies have shown that the increase in triglycerides contributes to increases in IFC $[8,9]$.

At present, improving IFC has become an important objective in the modern pig breeding program [10], especially in China [11]. However, it is difficult to improve IFC by traditional breeding methods. Although the heritability of IFC is relatively high $\left(\mathrm{h}^{2}=0.25-0.50\right)$ [12], it is still impossible to assess exact IFC in the offspring. Accurate measurement of IFC still requires slaughtering pigs, which is costly to implement. As compared to traditional breeding methods, marker-assisted selection (MAS) and genome selection (GS) technology are ideal ways to improve IFC in pigs. However, in comparison with MAS, many pig farms cannot cover the cost of GS technology. Thus, MAS is an attractive approach to improve IFC in pigs. Several candidate genes and causative mutations for IFC have been identified in previous studies, such as FABP3 (rs1110770079) [13], LIPE (rs328830166) [14], IGF1 (rs322131043), IGF1 (rs341412920) [15], IGF2 (g.3072G > A) [16], LEP (rs45431504) [17], LEPR (rs45435518) [18], MC4R (rs81219178) [19], PHKG1 (rs697732005) [20], RETN (rs327132149) [21], RYR1 (rs344435545) [22], SCD (rs80912566) [18] and UBE3C (rs81329544) [23].

In general, the phenotypic correlation between backfat (BF) thickness and IFC is moderate and positive. Therefore, increasing IFC often leads to increased BF thickness [24]. The increased BF thickness in turn could result in a decrease in lean meat percentage, which adversely affects the lean meat yield. Thus, it is especially necessary to find SNPs that could increase IFC but not the BF thickness.

Suhuai pig is a new lean-type pig breed. Briefly, after 23 years of successive breeding of the crossbred offspring of the Large White Pig and Huai Pig, a new breed was developed, called the Xinhuai Pig, which contains 50\% Large White and 50\% Huai pig (1954-1977). Subsequently, Large White pigs were again used to cross with Xinhuai pigs, and their offspring were selected and bred for 12 years to obtain a new national lean type breed called the Suhuai pig, which contains $25 \%$ Chinese Huai pig and 75\% Large White (1998-2010) (Figure 1). At present, Suhuai pigs are distributed in over 20 provinces such as Jiangsu and Anhui. There are more than 10,000 Suhuai sows, which produce more than 12,000 tons of pork per year. The lean meat percentage of carcass is about $57 \%$, and the average daily gain from $30 \mathrm{~kg}$ to $90 \mathrm{~kg}$ is about $660 \mathrm{~g}$. Huai pig is one of the North Chinese pig breeds with the characteristics of Chinese local pig such as high-meat quality and high-forage tolerance [25]. Historical data showed that Huai pig has relatively high IFC [26]. In contrast, Large White pig, a commercial breed that is known for its lean carcass and rapid growth rate, shows lower fat deposition capacity [27]. Therefore, as a synthetic crossbreed, Suhuai pig has the high forage tolerance of the Chinese Huai pig, as well as the rapid growth rate and high lean meat yield of the Large White breed.

IFC is affected by many factors, such as heredity, nutrition, environment, and feeding methods. A previous study has shown that the CV of IFC was large within Suhuai pigs [28]. In the present study, all of the Suhuai pigs were raised under commercial conditions using the same feed. Considering that the heritability of IFC is relatively high, we speculate that the variation of IFC of Suhuai pigs is mainly due to genetic factors. Based on this, Suhuai pig is a suitable genetic material for identifying the molecular markers for IFC. The present study aimed to explore the association of the above-mentioned 13 SNPs with IFC and ABT of Suhuai pigs, and to find molecular markers that indicate higher IFC but not ABT, which will contribute to early selection of replacement pigs. 


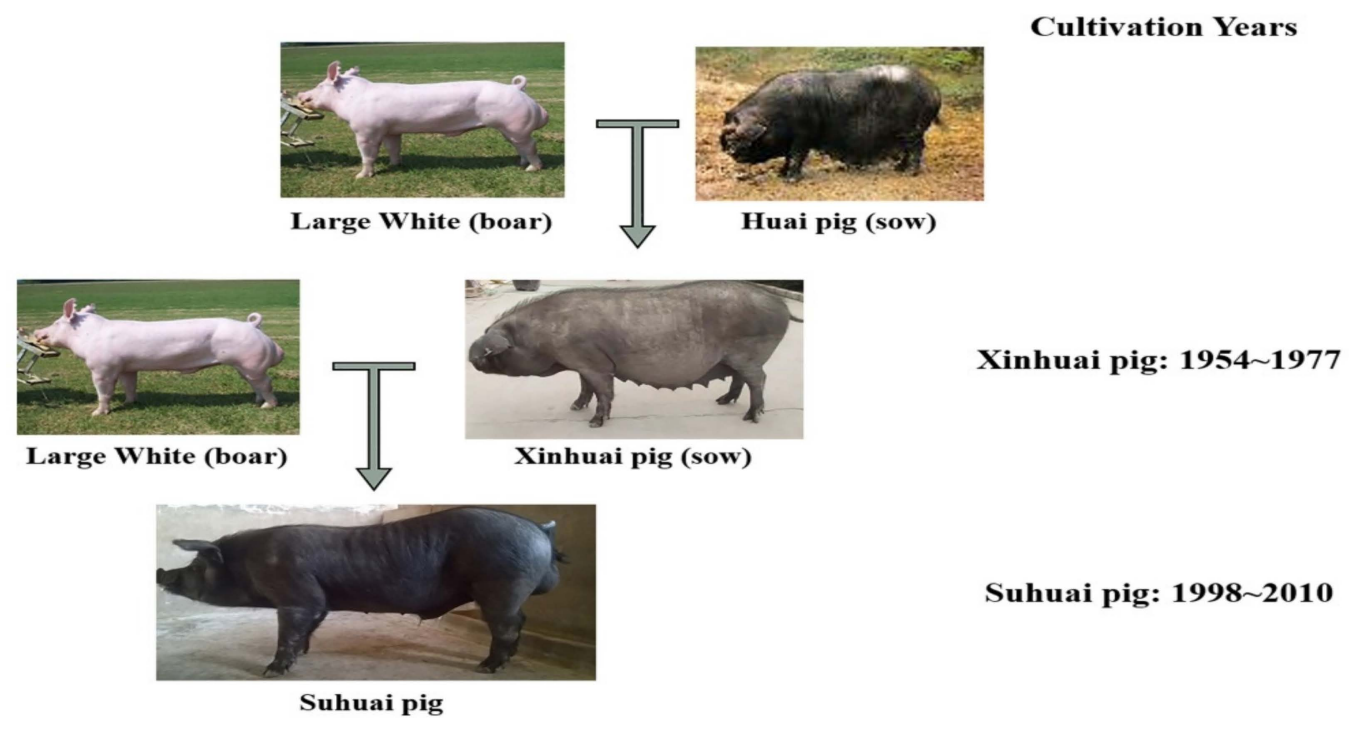

Figure 1. The cultivation process of Suhuai pig.

\section{Materials and Methods}

\subsection{Ethics Statement}

All experimental animals were raised according to Guidelines for the Care and Use of Laboratory Animals prepared by the Institutional Animal Welfare and Ethics Committee of Nanjing Agricultural University, Nanjing, China. All experimental protocols were approved by the Nanjing Agricultural University Animal Care and Use Committee (Certification No.: SYXK (Su) 2017-0007).

\subsection{Animals and Phenotype Measurements}

A total of 330 Chinese Suhuai pigs were used in this study, including 247 barrows and 83 females. Experimental pigs were all raised under standard indoor conditions in Huaiyin breeding farm (Huaian, China). Since these pigs were not raised at the same time and the same age (219.10 \pm 1.10 day), they could only be slaughtered at the same slaughterhouse in 3 batches in Jinyuan Meat Products Co., Ltd. (Huaian, China) when these pigs reached market weight (80-90 kg). Age, carcass weight, sex, batch, and pedigree were recorded in this study. Longissimus Dorsi (LD) muscle samples from the last rib of the left half of the carcasses were collected and used to determine IFC by the Soxhlet extraction method [29]. Ear tissues from the end of the right ear were collected and stored in $75 \%$ alcohol for genomic DNA extraction. The BF thicknesses were measured by digital caliper at 3 positions (the shoulder, the last rib and the last lumbar vertebrae) on the right side of the carcass. After that, ABT $(\mathrm{ABT}=$ the average values of the results obtained at the 3 positions) was calculated.

\subsection{Isolation of Genomic DNA and SNPS Genotyping}

The genomic DNA was isolated from ear tissue using the standard phenol-chloroform protocol method [30]. The DNA concentration was measured with a Nanodrop 2000 spectrophotometer (Thermo Fisher Scientific Inc, Waltham, MA, USA) and the integrity of the DNA was checked on 1.5\% agarose gel with an FR-250 electrophoresis apparatus (Furi Technology Co., Ltd., Shanghai, China). Only high-quality genomic DNAs from all samples were used for subsequent genotyping. The polymerase chain reaction-restriction fragment length polymorphism (PCR-RFLP) method and the improved multiplex ligation detection reaction (iMLDR) technique [31] were used to analyze the polymorphisms of 13 SNPs from the 12 candidate genes (Supplementary Table S1). Among these SNPs, 11 were genotyped through iMLDR in one ligation reaction, including LIPE (rs328830166), IGF1 (rs341412920), IGF1 (rs322131043), IGF2 (g.3072G > A), LEP (rs45431504), LEPR (rs45435518), MC4R (rs81219178), RETN (rs327132149), RYR1 (rs344435545), SCD (rs80912566) and UBE3C (rs81329544). 
Fragments covering these 11 SNPs were amplified using a multiplex of PCR reactions. The multiplex PCR reaction, performed in a $20 \mu \mathrm{L}$ total volume, contained $1 \times$ GC-I buffer (Takara, Dalian, China), $3.0 \mathrm{mM} \mathrm{Mg}{ }^{2+}, 0.3 \mathrm{mM}$ dNTPs, $1 \mathrm{U}$ of Hot-Start Taq DNA polymerase (Takara, Dalian, China), $1 \mu \mathrm{L}$ of primer mixture, and $20 \mathrm{ng}$ of genomic DNA. The PCR program was as follow: $95^{\circ} \mathrm{C}$ for $2 \mathrm{~min}, 11$ cycles $\left(94{ }^{\circ} \mathrm{C}\right.$ for $20 \mathrm{~s}, 65^{\circ} \mathrm{C}-0.5^{\circ} \mathrm{C} /$ cycle for $40 \mathrm{~s}$, and $72^{\circ} \mathrm{C}$ for $1 \mathrm{~min}$ and $\left.30 \mathrm{~s}\right), 24$ cycles $\left(94^{\circ} \mathrm{C}\right.$ for $20 \mathrm{~s}, 59^{\circ} \mathrm{C}$ for $30 \mathrm{~s}$, and $72{ }^{\circ} \mathrm{C}$ for $1 \mathrm{~min}$ and $30 \mathrm{~s}$ ), $72{ }^{\circ} \mathrm{C}$ for $2 \mathrm{~min}$, and hold at $4{ }^{\circ} \mathrm{C}$. The purification reaction, performed in a new volume, contained $10 \mu \mathrm{L}$ of each PCR product, 5U SAP and 2U Exonuclease I at $37^{\circ} \mathrm{C}$ for $1 \mathrm{~h}$ and at $75{ }^{\circ} \mathrm{C}$ for $15 \mathrm{~min}$. The ligation reaction, performed in a $10 \mu \mathrm{L}$ final volume, contained $1 \mu \mathrm{L}$ of $10 \times$ ligation buffer, $0.25 \mu \mathrm{L}$ of Taq DNA Ligase (NEB Biotechnology, Beijing, China), $0.4 \mu \mathrm{L}$ of $5^{\prime}$ ligation primer mixture, $0.4 \mu \mathrm{L}$ of $3^{\prime}$ ligation primer mixture, $2 \mu \mathrm{L}$ of purified PCR product mixture and $6 \mu \mathrm{L}$ of double distilled water $\left(\mathrm{ddH}_{2} \mathrm{O}\right)$. The ligation cycling program was 38 cycles $\left(94^{\circ} \mathrm{C}\right.$ for $1 \mathrm{~min}$ and $56^{\circ} \mathrm{C}$ for $4 \mathrm{~min}$ ), and a hold at $4{ }^{\circ} \mathrm{C}$. A total of $0.5 \mu \mathrm{L}$ of ligation product was loaded into an $\mathrm{ABI} 3730 \mathrm{XL}$, and the raw data were analyzed using the GeneMapper 4.1 software program (Thermo Fisher Scientific Inc, Waltham, MA, USA). All of the iMLDR primers are presented in Supplementary Table S1.

Only the polymorphisms of FABP3 (rs1110770079) and PHKG1 (rs697732005) were assessed using the PCR-RFLP method due to the failure of the iMLDR technique. For PCR-RFLP, the sequences for these 2 genes were obtained from the GenBank database (NLM, Bethesda, MD, USA). The primers of these 2 SNPs were designed by Primer Premier 6.0 software (Premier Biosoft International, Palo Alto, CA, USA) (Supplementary Table S1). PCR reaction was performed in a final volume of $25 \mu \mathrm{L}$, containing $1 \mu \mathrm{L}$ of the template DNA (50 ng/ $\mu \mathrm{L}$ ), $1 \mu \mathrm{L}$ of each primer, $22 \mu \mathrm{L} 1.3 \times$ Taq buffer. Cycling conditions were $98^{\circ} \mathrm{C}$ for $2 \mathrm{~min} ; 40$ cycles at $98^{\circ} \mathrm{C}$ for $10 \mathrm{~s}, 57^{\circ} \mathrm{C}$ for $40 \mathrm{~s}, 7{ }^{\circ} \mathrm{C}$ for $1 \mathrm{~min}$; and a final extension at $72{ }^{\circ} \mathrm{C}$ for $5 \mathrm{~min}$. The quality of the PCR product was analyzed by using $1.5 \%$ agarose gel electrophoresis. Genotyping was performed by the TSINGKE Company (Nanjing, China).

\subsection{Statistical Analysis}

Statistical analysis of IFC and ABT of the 330 Suhuai pigs was performed using GraphPad Prism 6 (GraphPad Software Inc, La Jolla, CA, USA) with the quartile method.

Phenotypic correlations of IFC and ABT were calculated using SAS 9.2 software (SAS Institute lnc, Cary, NC, USA). To estimate genetic correlations of IFC and ABT, all the phenotypes were corrected for sex and batch as fixed effects and sample identity (ID) as a random variable using DMU software [32].

In this study, genetic diversity indices were calculated to explore the genetic structure of all SNPs. The minimal number of genotypes used in the analysis was 3 , and the total number of animals analyzed here was 327-330. The genotype and allele frequencies were calculated using Microsoft Excel 2013. The heterozygosity (He), homozygosity (Ho) and polymorphic information content (PIC) were estimated using Power Marker V3.0 software [33].

Here, variance analyses were performed using SAS 9.2 software (SAS Institute lnc, Cary, NC, USA). Sex and batch were considered as fixed effects in the models (1) and (2), because sex and batch had significantly effects on both IFC and ABT in variance analyses. We also found that age had significant effects on IFC, and carcass weight had significantly effects on ABT. Thus, age was used as the covariate for IFC in model (1), and carcass weight was used as the covariate for ABT in model (2).

Association analysis of each SNP with IFC and ABT was performed using the PROC GLM procedure of module of SAS 9.2 software.

For IFC, the following model was applied:

$$
Y_{i j k l m}=\mu+G_{i}+B_{j}+S_{k}+D_{l}+K_{m}+e_{i j k l m}
$$

For ABT, the following model was applied:

$$
Y_{i j k l m}=\mu+G_{i}+B_{j}+S_{k}+W_{l}+K_{m}+e_{i j k l m},
$$


In models (1) and (2), $\mathrm{Y}_{\mathrm{ijlkm}}$ represents the vector of the phenotypic value of the trait under study, $\mu$ in these 2 models is the population mean of IFC and ABT, respectively, $G_{i}, B_{j}$ and $S_{k}$ refer to fixed effects of SNPs, batch and sex, respectively, $D_{1}$ represents the covariate of age for IFC, $W_{1}$ is the covariate of carcass weight for $\mathrm{ABT}, \mathrm{K}_{\mathrm{m}}$ is the random variable of kinship matrix using pedigree, and $\mathrm{e}_{\mathrm{ijklm}}$ represents the random error. All statistical analyses were considered significant at $p<0.05$.

\section{Results}

\subsection{Descriptive Statistics for IFC and ABT}

Descriptive statistics for IFC and ABT of 330 Suhuai pigs are shown in Figure 2 and Table 1. The means of IFC and ABT were $1.99 \pm 0.03 \%$ and $26.68 \pm 0.28 \mathrm{~mm}$, respectively. The medians of IFC and ABT were $1.86 \%$ and $26.40 \mathrm{~mm}$, respectively. The CVs of IFC and ABT were $31.21 \%$ and $19.36 \%$, respectively.

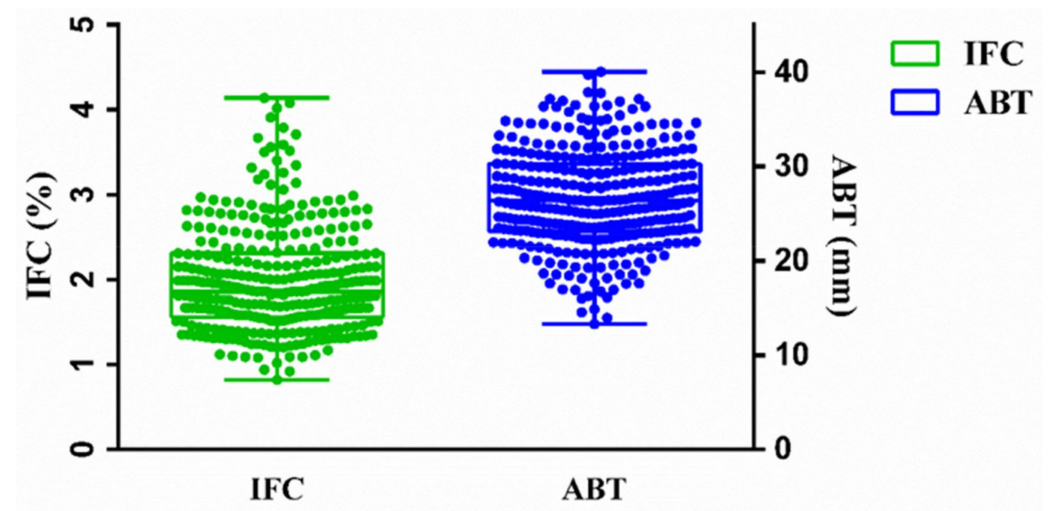

Figure 2. Statistical analysis of IFC and ABT of Suhuai pigs. IFC = intramuscular fat content (green box); ABT = average backfat thickness (blue box); statistical analysis was performed using GraphPad Prism 6 with the quartile method.

Table 1. Descriptive statistics of the intramuscular fat content (IFC) and average backfat thickness $(\mathrm{ABT})$ in 330 Suhuai pigs.

\begin{tabular}{cccccc}
\hline Trait & Number & Mean \pm SE & Max & Min & CV\% \\
\hline IFC & 330 & $1.99 \pm 0.03 \%$ & $4.14 \%$ & $0.82 \%$ & 31.21 \\
ABT & 330 & $26.68 \pm 0.28 \mathrm{~mm}$ & $40.02 \mathrm{~mm}$ & $13.13 \mathrm{~mm}$ & 19.36 \\
\hline
\end{tabular}

Mean \pm SE represents the means with standard errors for diverse genotypes; Max refers to the maximum value of the phenotype; Min refers to the minimum value of the phenotype; $\mathrm{CV}=$ coefficient of variation.

\subsection{Estimates of Phenotypic and Genetic Correlations of Suhuai Pigs}

The phenotypic and genetic correlations between IFC and ABT were calculated. Phenotypic correlation between IFC and ABT was $0.32(p<0.01)$ and genetic correlation was $0.34(p<0.01)$. These results suggested a moderate correlation between IFC and ABT of Suhuai pigs [34], and thus it was possible to increase IFC without increasing ABT.

\subsection{Genetic Parameters of These SNPS}

The genotypic and allele frequencies, as well as other genetic parameters (He, Ho and PIC), were estimated for the Suhuai pigs (Table 2). Of these, the PIC values of most SNPs were moderate $(0.25<$ PIC < 0.5), including the LIPE (rs328830166), IGF2 (g.3072G > A), MC4R (rs81219178), SCD (rs80912566), UBE3C (rs81329544), FABP3 (rs1110770079), PHKG1 (rs697732005). The values of He, Ho and PIC of the $\operatorname{LEP}(0.15,0.85$ and 0.14$), \operatorname{LEPR}(0.16,0.84$ and 0.15$), \operatorname{RETN}(0.06,0.94$ and 0.06$)$ and $R Y R 1(0.06,0.94$ and 0.06$)$ were low, due to the lack of homozygous mutant genotypes. Moreover, the value of PIC in the IGF1 (0.09) SNP was low due to the absence of one homozygous genotype. 
Table 2. Genetic parameters of 13 SNPs in 12 previously reported candidate genes for IFC of Suhuai pigs.

\begin{tabular}{|c|c|c|c|c|c|c|c|}
\hline \multirow{2}{*}{ Gene (SNP) } & \multirow{2}{*}{ Chromosome } & \multirow{2}{*}{ Genotype (Number) } & \multicolumn{2}{|c|}{ Frequency } & \multirow{2}{*}{ HE } & \multirow{2}{*}{ HO } & \multirow{2}{*}{ PIC } \\
\hline & & & Genotype & Allele & & & \\
\hline \multirow{3}{*}{$\begin{array}{c}F A B P 3 \\
\text { rs1110770079 }\end{array}$} & \multirow{3}{*}{6} & GG (82) & 0.25 & $0.44(\mathrm{G})$ & 0.36 & 0.64 & 0.37 \\
\hline & & GT (117) & 0.36 & & & & \\
\hline & & TT (123) & 0.38 & $0.56(\mathrm{~T})$ & & & \\
\hline \multirow{3}{*}{$\begin{array}{c}\text { LIPE } \\
\text { rs328830166 }\end{array}$} & \multirow{3}{*}{6} & AA (53) & 0.16 & 0.40 (A) & 0.48 & 0.52 & 0.36 \\
\hline & & AG (157) & 0.48 & & & & \\
\hline & & GG (120) & 0.36 & $0.60(\mathrm{G})$ & & & \\
\hline \multirow{3}{*}{$\begin{array}{c}\text { IGF1 } \\
\text { rs341412920 }\end{array}$} & \multirow{3}{*}{5} & $\mathrm{CC}(8)$ & 0.02 & $0.16(C)$ & 0.28 & 0.72 & 0.24 \\
\hline & & CT (90) & 0.28 & & & & \\
\hline & & TT (228) & 0.70 & $0.84(\mathrm{~T})$ & & & \\
\hline \multirow{2}{*}{$\begin{array}{c}\text { IGF1 } \\
\text { rs322131043 }\end{array}$} & \multirow{2}{*}{5} & AG (32) & 0.10 & $0.05(\mathrm{~A})$ & 0.10 & 0.90 & 0.09 \\
\hline & & GG (298) & 0.90 & $0.95(G)$ & & & \\
\hline \multirow{3}{*}{$\begin{array}{c}I G F 2 \\
\text { g. } 3072 \mathrm{G}>\mathrm{A}\end{array}$} & \multirow{3}{*}{2} & AA (62) & 0.19 & $0.42(\mathrm{~A})$ & 0.46 & 0.54 & 0.37 \\
\hline & & AG (151) & 0.46 & & & & \\
\hline & & GG (117) & 0.35 & $0.58(\mathrm{G})$ & & & \\
\hline \multirow{3}{*}{$\begin{array}{c}L E P \\
\mathrm{rs} 45431504\end{array}$} & \multirow{3}{*}{18} & CC (1) & 0.01 & $0.08(C)$ & 0.15 & 0.85 & 0.14 \\
\hline & & CT (51) & 0.15 & & & & \\
\hline & & TT (278) & 0.84 & $0.92(\mathrm{~T})$ & & & \\
\hline \multirow{3}{*}{$\begin{array}{c}L E P R \\
\text { rs45435518 }\end{array}$} & \multirow{3}{*}{6} & CC (2) & 0.01 & 0.09 (C) & 0.16 & 0.84 & 0.15 \\
\hline & & CT (53) & 0.16 & & & & \\
\hline & & TT (274) & 0.83 & $0.91(\mathrm{~T})$ & & & \\
\hline \multirow{3}{*}{$\begin{array}{c}M C 4 R \\
\text { rs81219178 }\end{array}$} & \multirow{3}{*}{1} & AA (109) & 0.33 & $0.60(\mathrm{~A})$ & 0.53 & 0.47 & 0.37 \\
\hline & & AG (175) & 0.53 & & & & \\
\hline & & GG (45) & 0.14 & $0.40(\mathrm{G})$ & & & \\
\hline \multirow{3}{*}{$\begin{array}{c}\text { PHKG1 } \\
\text { rs697732005 }\end{array}$} & \multirow{3}{*}{3} & AA (184) & 0.57 & $0.70(\mathrm{~A})$ & 0.26 & 0.74 & 0.33 \\
\hline & & AG (85) & 0.26 & & & & \\
\hline & & GG (53) & 0.16 & $0.30(\mathrm{G})$ & & & \\
\hline & & AA (1) & 0.00 & $0.03(\mathrm{~A})$ & 0.06 & 0.94 & 0.06 \\
\hline RETN & 2 & AG (20) & 0.06 & & & & \\
\hline & & GG (309) & 0.94 & $0.97(\mathrm{G})$ & & & \\
\hline & & CC (309) & 0.94 & 0.97 (C) & 0.06 & 0.94 & 0.06 \\
\hline 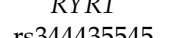 & 6 & CT (20) & 0.06 & & & & \\
\hline rs34443b54b & & TT (1) & 0.00 & $0.03(\mathrm{~T})$ & & & \\
\hline & & CC (59) & 0.18 & $0.41(\mathrm{C})$ & 0.47 & 0.53 & 0.37 \\
\hline SCD & 14 & СТ (154) & 0.47 & & & & \\
\hline rs80912566 & & TT (117) & 0.35 & $0.59(\mathrm{~T})$ & & & \\
\hline & & AA (14) & 0.04 & $0.22(\mathrm{~A})$ & 0.35 & 0.65 & 0.28 \\
\hline UBE3C & 18 & AG (117) & 0.35 & & & & \\
\hline rs81329544 & & GG (199) & 0.60 & $0.78(\mathrm{G})$ & & & \\
\hline
\end{tabular}




\subsection{Association Analysis between SNPs and IFC and ABT}

Association analysis results of SNPs with IFC and ABT are shown in Table 3. Of the 13 evaluated SNPs, only the FABP3 (rs1110770079) SNP was associated with IFC $(p<0.05)$. Among the three genotypes of the FABP3 gene (rs1110770079), IFC of the GG genotype $(2.19 \pm 0.09 \%)$ was significantly higher than that of the TT genotype $(1.93 \pm 0.07 \%)$. In addition, the results revealed a tendency $(p<0.1)$ for differences among the RYR1 (rs344435545) and SCD (rs80912566) genotypes for IFC. However, none of these SNPs was associated with ABT.

Table 3. Association analysis of 13 SNPs in 12 previously reported candidate genes with the intramuscular fat content (IFC) and average backfat thickness (ABT) of Suhuai pigs.

\begin{tabular}{|c|c|c|c|c|c|c|}
\hline \multirow{2}{*}{ Gene (SNP) } & \multirow{2}{*}{ Genotype } & \multirow{2}{*}{ Number } & \multicolumn{2}{|c|}{ IFC (\%) } & \multicolumn{2}{|c|}{ ABT (mm) } \\
\hline & & & Mean \pm SE & $p$ Value & Mean \pm SE & $p$ Value \\
\hline \multirow{3}{*}{$\begin{array}{c}F A B P 3 \\
\text { rs1110770079 }\end{array}$} & GG & 82 & $2.19 \pm 0.09^{a}$ & \multirow{3}{*}{0.0230} & $26.89 \pm 0.57$ & \multirow{3}{*}{0.6040} \\
\hline & GT & 117 & $2.13 \pm 0.07^{a b}$ & & $26.18 \pm 0.49$ & \\
\hline & $\mathrm{TT}$ & 123 & $1.93 \pm 0.07^{b}$ & & $26.49 \pm 0.52$ & \\
\hline \multirow{3}{*}{$\begin{array}{c}L I P E \\
\text { rs328830166 }\end{array}$} & AA & 53 & $2.05 \pm 0.08$ & \multirow{3}{*}{0.4204} & $26.82 \pm 0.70$ & \multirow{3}{*}{0.9068} \\
\hline & AG & 157 & $1.95 \pm 0.05$ & & $28.14 \pm 4.53$ & \\
\hline & GG & 120 & $2.03 \pm 0.06$ & & $27.82 \pm 1.03$ & \\
\hline \multirow{3}{*}{$\begin{array}{c}I G F 1 \\
\text { rs341412920 }\end{array}$} & $\mathrm{CC}$ & 8 & $1.92 \pm 0.20$ & \multirow{3}{*}{0.5286} & $26.67 \pm 1.61$ & \multirow{3}{*}{0.9857} \\
\hline & $\mathrm{CT}$ & 90 & $1.94 \pm 0.06$ & & $26.52 \pm 0.51$ & \\
\hline & TT & 228 & $2.02 \pm 0.04$ & & $26.61 \pm 0.35$ & \\
\hline \multirow{2}{*}{$\begin{array}{c}I G F 1 \\
\text { rs322131043 }\end{array}$} & AG & 32 & $2.00 \pm 0.10$ & \multirow{2}{*}{0.9981} & $26.50 \pm 0.31$ & \multirow{2}{*}{0.5349} \\
\hline & GG & 298 & $2.00 \pm 0.04$ & & $27.22 \pm 1.22$ & \\
\hline \multirow{3}{*}{$\begin{array}{c}I G F 2 \\
\text { g. } 3072 \mathrm{G}>\mathrm{A}\end{array}$} & AA & 62 & $2.01 \pm 0.07$ & \multirow{3}{*}{0.9340} & $26.50 \pm 0.44$ & \multirow{3}{*}{0.4130} \\
\hline & AG & 151 & $2.00 \pm 0.05$ & & $26.59 \pm 0.37$ & \\
\hline & GG & 117 & $1.98 \pm 0.06$ & & $26.21 \pm 3.20$ & \\
\hline \multirow{4}{*}{$\begin{array}{c}L E P \\
\text { rs45431504 } \\
L E P R \\
\text { rs45435518 }\end{array}$} & $\mathrm{CT}$ & 51 & $1.98 \pm 0.08$ & \multirow[b]{2}{*}{0.7460} & $26.11 \pm 0.65$ & \multirow[b]{2}{*}{0.3260} \\
\hline & TT & 278 & $2.01 \pm 0.04$ & & $26.78 \pm 0.32$ & \\
\hline & $\mathrm{CT}$ & 53 & $1.88 \pm 0.09$ & \multirow{2}{*}{0.1070} & $26.10 \pm 0.67$ & \multirow{2}{*}{0.4410} \\
\hline & $\mathrm{TT}$ & 274 & $2.02 \pm 0.04$ & & $26.63 \pm 0.32$ & \\
\hline \multirow{3}{*}{$\begin{array}{c}M C 4 R \\
\operatorname{rs} 81219178\end{array}$} & AA & 109 & $2.04 \pm 0.05$ & \multirow{3}{*}{0.2504} & $26.12 \pm 0.67$ & \multirow{3}{*}{0.7776} \\
\hline & AG & 175 & $1.95 \pm 0.05$ & & $26.65 \pm 0.32$ & \\
\hline & GG & 45 & $2.10 \pm 0.09$ & & $26.82 \pm 0.70$ & \\
\hline & AA & 187 & $1.98 \pm 0.07$ & & $26.10 \pm 0.41$ & \\
\hline PHKG1 & AG & 89 & $2.14 \pm 0.08$ & 0.2221 & $27.18 \pm 0.52$ & 0.1650 \\
\hline rs697732005 & GG & 36 & $2.02 \pm 0.12$ & & $26.74 \pm 0.77$ & \\
\hline RETN & AG & 20 & $1.96 \pm 0.13$ & & $27.81 \pm 1.03$ & \\
\hline rs327132149 & GG & 309 & $2.00 \pm 0.04$ & 0.7730 & $26.50 \pm 0.31$ & 0.2080 \\
\hline$R Y R 1$ & $\mathrm{CC}$ & 309 & $2.01 \pm 0.04$ & & $26.61 \pm 0.31$ & \\
\hline rs344435545 & $\mathrm{CT}$ & 20 & $1.78 \pm 0.13$ & 0.0850 & $26.56 \pm 1.02$ & 0.9550 \\
\hline & $\mathrm{CC}$ & 59 & $2.09 \pm 0.08$ & & $27.01 \pm 0.46$ & \\
\hline$S C D$ & $\mathrm{CT}$ & 154 & $1.88 \pm 0.05$ & 0.0510 & $26.76 \pm 0.48$ & 0.1666 \\
\hline rs80912566 & $\mathrm{TT}$ & 117 & $2.01 \pm 0.06$ & & $26.42 \pm 0.37$ & \\
\hline & AA & 14 & $1.79 \pm 0.15$ & & $27.22 \pm 1.22$ & \\
\hline UBE3C & AG & 117 & $1.95 \pm 0.06$ & 0.1659 & $26.50 \pm 0.44$ & 0.8540 \\
\hline rs81329544 & GG & 199 & $2.04 \pm 0.05$ & & $26.59 \pm 0.37$ & \\
\hline
\end{tabular}

Mean \pm SE represents the means with standard errors for different genotypes; Superscripts with different lowercase letters indicate a significant difference between genotypes $(p<0.05)$.

\section{Discussion}

IFC and ABT are important economic traits for meat quality. Research on the genetic basis of these two traits has long been the focus of attention [4-6]. Recent studies using RNA sequencing identified 5 genes that affect fat deposition [35]. Genome-wide association studies indicated that the CTN1 gene is associated with IFC [36]. IFC is a relevant trait for high-quality meat products [37], but high BF thickness leads to a decrease in lean meat percentage [38]. Therefore, this study aimed to find molecular markers that are significantly associated with IFC, but do not change ABT of Suhuai 
pigs. A total of 330 Suhuai pigs were measured for IFC and ABT. The CVs for IFC and ABT were high, perhaps due to the fact that the Suhuai is a new synthetic hybrid breed of pig, and there was a difference in the age and carcass weight of this population. The mean of IFC was low, but compared with Large White, Suhuai pigs had higher IFC and BF. Phenotypic and genetic correlations between IFC and ABT were moderate. This suggests that it should be possible to increase IFC without changing BF thickness. Suzuki et al. [12] reported that the phenotypic correlation between IFC and ABT was moderate, similar to our results.

In the present study, 13 SNPs from 12 previously reported candidate genes for IFC were genotyped, and these SNPs were polymorphic in Suhuai pigs. Among these SNPs, low polymorphisms of the alleles IGF1 (rs322131043), LEP (rs45431504), LEPR (rs45435518), RETN (rs327132149) and RYR1 (rs344435545) were observed. These results indicated that there was a strong selection pressure on several traits that were associated with SNPs in this study, such as growth rate, yield of lean meat, BF thickness and so on. The lower values of PIC and He in the IGF1 (rs322131043), LEP (rs45431504), LEPR (rs45435518) and RETR (rs327132149) provided additional evidence for the strong selection pressure. For example, the $R Y R 1$ (rs344435545) SNP is a missense mutation that causes a change in protein ( $\mathrm{Arg}^{615} \rightarrow \mathrm{Cys}^{615}$ ), and this mutation results in muscle dysfunction and finally porcine stress syndrome (PSS) [39]. This disease may cause pigs to produce pale soft exudative meat (PSE) [22]. Therefore, breeders have been working hard to eliminate deleterious alleles in recent decades.

Association analysis of the 13 evaluated SNPs with IFC and ABT was performed. Associations of all SNPs with IFC were not significant, except for the FABP3 (rs1110770079) SNP. These 13 SNPs did not associate with $\mathrm{ABT}$ of Suhuai pigs; the possible reasons were that some of these genes were not causal genes for BF thickness, such as PHKG1, RETN, SCD, and UBE3C. The FABP3 gene is one member of the fatty acid binding protein family, which plays a critical role in intracellular fatty acid transport by binding lipids and regulating metabolic homeostasis [40]. The FABP3 gene might be responsible for IFC and is often regarded as a candidate gene [13]. Chen et al. [41] found that the FABP3 (HinfI) SNP was associated with IFC in both Yanan $(p<0.001)$ and DLY $(p<0.05)$ pigs, but did not significantly affect the BF thickness, strikingly similar to the results in our study. Although the rs344435545 SNP in the $R Y R 1$ gene is likely to cause an increase in the incidence of porcine stress syndrome, there is a strong correlation between IFC and RYR1 gene expression level [42] and as this mutation can cause a decrease of BF thickness, it has been considered as an example of balanced selection [43]. The SCD (rs80912566) SNP could affect the fatty acid composition and IFC within the Duroc population [18]. Moreover, the $S C D$ gene was identified as a candidate gene related to IFC between pigs with high and low IFC [44]. The result from Henriquez-Rodriguez et al. [45] showed that the SCD (rs80912566) SNP was associated with fat composition but not with fat content. Their results were consistent with our study. It is worth noting that the results in Table 3 revealed a tendency $(p<0.1)$ of association between the RYR1 (rs344435545) and SCD (rs80912566) with IFC. We speculate that these two SNPs have small effects on IFC or these may be only in linkage disequilibrium with the causative mutation of IFC.

The IGF1 gene affects the regulation of adipogenesis. Several results suggested a degree of positive correlation between the IGF1 gene expression and adipocyte content [15], and within the QTLs that affect IFC and BF thickness. Similar to the IGF1 gene, the LEP and LEPR genes also play a role in adipogenesis, and several studies have found that LEP (rs45431504) and LEPR (rs45435518) are polymorphic and could significantly influence IFC and BF thickness [46-48]. The RETN gene is located on SSC2, and RETN (rs327132149) was significantly associated with the abdominal fat weight, BF thickness and IFC [21,49]. On the contrary, IGF1 (rs322131043), LEP (rs45431504), LEPR (rs45435518) and RETN (rs327132149) were not significantly associated with IFC and ABT in our study and might be strongly selected for these 3 genes in Suhuai population, resulting in low polymorphisms in these SNPs.

The LIPE gene has long been considered as a candidate gene that could affect IFC deposition due to resolving fat [14,50]. Burgos et al. [16] reported that IGF2 (g.3072G > A) could affect pig carcass traits and IFC in Large White $\times$ Landrace populations. On the contrary, Aslan et al. [51] found that the IGF2 (g.3072G > A) SNP may not affect IFC in Pietrain, Duroc and Large White populations. 
Supakankul et al. [23] reported that these 2 porcine UBE3C polymorphisms (rs81329544 and rs32466023) were associated with IFC and fatty acid composition. The UBE3C gene is considered a potential candidate gene for fat deposition in muscle because of its location on SSC18, near the QTLs for IFC and FA composition [52]. The PHKG1 gene is related to glycolysis potential and could affect pork quality. A previous study indicated that there was a point mutation (rs330928088) in a splice acceptor site of intron 9 in the PHKG1 gene. This point mutation gave rise to the $32 \mathrm{bp}$ deletion in the open reading frame (ORF) and generated a premature stop codon [20]. However, the PHKG1 (rs330928088) SNP is not polymorphic and did not cause the $32 \mathrm{bp}$ deletion of Suhuai pigs. The SNP (rs697732005) in front of this PHKG1 (rs330928088) SNP is polymorphic, although it was not associated with IFC in this study. The MC4R gene has only one exon, located in the QTL for ABT on SSC1, and plays an important role in the regulation of energy homeostasis [53]. Several reports found that the MC4R gene could be associated with fat mass in humans [54] and IFC in Hu sheep [55]. Lyadskiy et al. [56] found no significant difference between the spinal fat thickness and the MC4R (rs81219178) SNP, similar to our results. Nevertheless, there was no significant difference in IFC between the three genotypes of the MC4R (rs81219178) in pigs [19]; this result is consistent with our study. The fact that the above-mentioned five SNPs were not significantly associated with IFC and ABT might be due to genetic heterogeneity. After all, Suhuai pig is a hybrid population containing Huai pig (25\%) and Large White (75\%).

These 13 SNPs of the 12 genes did not associate with ABT in Suhuai pigs. The possible reasons were that some of these genes were not causal genes for BF thickness, and other candidate genes of BF thickness may have heterogeneity between breeds. Finally, the FABP3 (rs1110770079) SNP was the genetic marker we were looking for, which could improve IFC without increasing BF thickness.

\section{Conclusions}

Our results showed that phenotypic and genetic correlations between IFC and ABT were moderate. These 13 SNPs of the 12 genes were polymorphic in Suhuai pigs. Among them, FABP3 (rs1110770079) SNP was associated with IFC $(p<0.05)$ but not with ABT, and this confirmed the importance of porcine $F A B P 3$ as a candidate gene for IFC of Suhuai pigs. The cost of genotyping tests is low, and farmers could select favorable genotype (GG) individuals according to the genotyping results for pig breeding. Further studies are necessary to confirm the finding.

Supplementary Materials: The following are available online at http://www.mdpi.com/2076-2615/9/11/858/s1, Table S1: Primer sequences and PCR products of 13 SNPs in 12 previously reported candidate genes for intramuscular fat content (IFC) in this study.

Author Contributions: Conceptualization, P.L. and R.H.; Formal analysis, B.W. and P.L.; Investigation, B.W., W.Z., C.G., H.L. (Hang Liu), H.L. (Huixia Li), P.N., Z.Z., Q.L. and J.Z.; Methodology, P.L. and R.H.; Project administration, P.L. and R.H.; Writing—original draft, B.W.; Writing—review \& editing, P.L. and R.H.

Funding: This work is financially supported by the National Natural Science Foundation $(31872318,31601923)$, the Key Project of Jiangsu Agricultural New Variety Innovation (PZCZ201732), the Ministry of Agriculture and Rural Affairs Joint Projects for the National High Quality and Lean Pig Breeding (19190540), the project of Jiangsu Agricultural (pig) Industry Technology System (JATS(2018)275) and the Construction of Huaian Academy of Nanjing Agricultural University (BM2017020).

Conflicts of Interest: The authors declare that they have no conflict of interest.

\section{References}

1. He, Y.; Yang, X.; Xia, J.; Zhao, L.; Yang, Y. Consumption of meat and dairy products in China: A review. Proc. Nutr. Soc. 2016, 75, 385-391. [CrossRef] [PubMed]

2. Wood, J.D. Consequences for meat quality of reducing carcass fatness. In Reducing Fat in Meat Animals; Elsevier Applied Science Press: New York, NY, USA, 1990; pp. 344-397.

3. Li, B.; Weng, Q.; Dong, C.; Zhang, Z.; Li, R.; Liu, J.; Jiang, A.; Li, Q.; Jia, C.; Wu, W. A Key Gene, PLIN1, Can Affect Porcine Intramuscular Fat Content Based on Transcriptome Analysis. Genes 2018, 9, 194. [CrossRef] [PubMed] 
4. Wood, J.D.; Enser, M.; Fisher, A.V.; Nute, G.R.; Sheard, P.R.; Richardson, R.I.; Hughes, S.I.; Whittington, F.M. Fat deposition, fatty acid composition and meat quality: A review. Meat Sci. 2008, 78, 343-358. [CrossRef] [PubMed]

5. Font-I-Furnols, M.; Guerrero, L. Consumer preference, behavior and perception about meat and meat products: An overview. Meat Sci. 2014, 98, 361-371. [CrossRef] [PubMed]

6. Gao, S.Z.; Zhao, S.M. Physiology, affecting factors and strategies for control of pig meat intramuscular fat. Recent Pat. Food Nutr. Agric. 2009, 1, 59-74. [CrossRef] [PubMed]

7. Cesar, A.S.; Regitano, L.C.; Koltes, J.E.; Fritz-Waters, E.R.; Lanna, D.P.; Gasparin, G.; Mourão, G.B.; Oliveira, P.S.; Reecy, J.M.; Coutinho, L.L. Putative regulatory factors associated with intramuscular fat content. PLOS ONE 2015, 10, e0128350. [CrossRef]

8. Fernandez, X.; Monin, G.; Talmant, A.; Mourot, J.; Lebret, B. Influence of intramuscular fat content on the quality of pig meat-1. Composition of the lipid fraction and sensory characteristics of $\mathrm{m}$. longissimus lumborum. Meat Sci. 1999, 53, 59-65. [CrossRef]

9. Bergeron, K.; Julien, P.; Davis, T.A.; Myre, A.; Thivierge, M.C. Long-chain n-3 fatty acids enhance neonatal insulin-regulated protein metabolism in piglets by differentially altering muscle lipid composition. J. Lipid Res. 2007, 48, 2396-2410. [CrossRef]

10. Ramayo-Caldas, Y.; Fortes, M.R.S.; Hudson, N.J.; Porto-Neto, L.R.; Bolormaa, S.; Barendse, W.; Kelly, M.; Moore, S.S.; Goddard, M.E.; Lehnert, S.A.; et al. A marker-derived gene network reveals the regulatory role of PPARGC1A, HNF4G, and FOXP3 in intramuscular fat deposition of beef cattle. J. Anim. Sci. 2014, 92, 2832-2845. [CrossRef]

11. Verbeke, W.; Liu, R. The impacts of information about the risks and benefits of pork consumption on Chinese consumers' perceptions towards, and intention to eat, pork. Meat Sci. 2014, 98, 766-772. [CrossRef]

12. Suzuki, K.; Irie, M.; Kadowaki, H.; Shibata, T.; Kumagai, M.; Nishida, A. Genetic parameter estimates of meat quality traits in Duroc pigs selected for average daily gain, longissimus muscle area, backfat thickness, and intramuscular fat content. J. Anim. Sci. 2005, 83, 2058-2065. [CrossRef] [PubMed]

13. Gerbens, F.; Rettenberger, G.; Lenstra, J.A.; Veerkamp, J.H.; te Pas, M.F. Characterization, chromosomal localization, and genetic variation of the porcine heart fatty acid-binding protein gene. Mamm. Genome 1997, 8, 328-332. [CrossRef] [PubMed]

14. Zhao, S.M.; Ren, L.J.; Chen, L.; Zhang, X.; Cheng, M.L.; Li, W.Z.; Zhang, Y.Y.; Gao, S.Z. Differential Expression of Lipid Metabolism Related Genes in Porcine Muscle Tissue Leading to Different Intramuscular Fat Deposition. Lipids 2009, 44, 1029-1037. [CrossRef] [PubMed]

15. Rey, A.; Isabel, B.; López-Bote, C.J.; Ayuso, M.; Fernández, A.; Óvilo, C.; Benítez, R.; Daza, A. Long term vitamin A restriction improves meat quality parameters and modifies gene expression in Iberian pigs1. J. Anim. Sci. 2015, 93, 2730-2744. [CrossRef]

16. Burgos, C.; Galve, A.; Moreno, C.; Altarriba, J.; Reina, R.; García, C.; López-Buesa, P. The effects of two alleles of IGF2 on fat content in pig carcasses and pork. Meat Sci. 2011, 90, 309-313. [CrossRef] [PubMed]

17. Gardan, D.; Gondret, F.; Louveau, I. Lipid metabolism and secretory function of porcine intramuscular adipocytes compared with subcutaneous and perirenal adipocytes. Ajp. Endocrinol. Metab. 2006, 291, E372-E380. [CrossRef] [PubMed]

18. Rosfreixedes, R.; Gol, S.; Pena, R.N.; Tor, M.; Ibáñezescriche, N.; Dekkers, J.C.M.; Estany, J. Genome-Wide Association Study Singles Out SCD and LEPR as the Two Main Loci Influencing Intramuscular Fat Content and Fatty Acid Composition in Duroc Pigs. PLoS ONE 2016, 11, e0152496. [CrossRef]

19. Choi, J.S.; Jin, S.K.; Jeong, Y.H.; Jung, Y.C.; Jung, J.H.; Shim, K.S.; Choi, Y.I. Relationships between Single Nucleotide Polymorphism Markers and Meat Quality Traits of Duroc Breeding Stocks in Korea. Asian Australas. J. Anim. Sci. 2016, 29, 1229-1238. [CrossRef]

20. Ma, J.; Yang, J.; Zhou, L.; Ren, J.; Liu, X.; Zhang, H.; Yang, B.; Zhang, Z.; Ma, H.; Xie, X.; et al. A splice mutation in the PHKG1 gene causes high glycogen content and low meat quality in pig skeletal muscle. PLoS Genet. 2014, 10, e1004710. [CrossRef]

21. Cieslak, J.; Nowacka-Woszuk, J.; Bartz, M.; Fijak-Nowak, H.; Grzes, M.; Szydlowski, M.; Switonski, M. Association studies on the porcine RETN, UCP1, UCP3 and ADRB3 genes polymorphism with fatness traits. Meat Sci. 2009, 83, 551-554. [CrossRef] 
22. Rojas, J.E.; Wilches, M.A.; Cepeda, L.A.; Garcés, M.F.; Suarez, M.A.; Baldrich, R.M.; Vélez, C.A.; Guerrero, M.F.; García, M.R.; Moreno, I.H. Molecular Diagnostics of Porcine Stress Syndrome Susceptibility Associated with the Arg615Cys Mutation Using Real-Time PCR with Fluorescent Hybridization Probes. Rev. Colomb. Anestesiol. 2008, 36, 11-18. [CrossRef]

23. Supakankul, P.; Mekchay, S. Effect of UBE3C polymorphisms on intramuscular fat content and fatty acid composition in Duroc pigs. Genet. Mol. Res. 2016, 15. [CrossRef] [PubMed]

24. Weng, Q. Comparison of Determination Methods of Porcine Intramuscular Fat Content and Correlation Analysis with Carcass and Meat Quality Traits; Nanjing Agric. Univ.: Nanjing, China, 2017.

25. Yang, J.; Zhou, L.; Liu, X.; Ma, H.; Xie, X.; Xiong, X.; Hou, L.; Huang, Y.; Chen, C.; Ma, J. A comparative study of meat quality traits between Laiwu and DLY pigs. Acta Vet. Zootech. Sin. 2014, 45, 1752-1759. [CrossRef]

26. Wei-Hua, X.U.; Kang, L.Z.; Lin, X.J.; Yang, Z.S.; Gao, W.P.; Wang, Z.C. Polymorphism Analysis of H-FABP Gene and Its Correlation with IMF Content in Huai Pig. J. Fujian Norm. Univ. 2014, 30, 76-80.

27. Liu, Y.; Yang, X.; Jing, X.; He, X.; Wang, L.; Liu, Y.; Liu, D. Transcriptomics Analysis on Excellent Meat Quality Traits of Skeletal Muscles of the Chinese Indigenous Min Pig Compared with the Large White Breed. Int. J. Mol. Sci. 2017, 19, 21. [CrossRef]

28. Wang, B.; Wang, H.; Xiang, M.A.; Guang, P.U.; Niu, P.; Zhang, Z.; Zhou, J.; Pinghua, L.I.; Huang, R. Analysis of intramuscular fat content in Suhuai pigs and its correlation with polymorphisms of IGF2 and SCD genes. Anim. Husb. Vet. Med. J. 2018, 50, 20-25.

29. Supakankul, P.; Mekchay, S. Association of NLK polymorphisms with intramuscular fat content and fatty acid composition traits in pigs. Meat Sci. 2016, 118, 61-65. [CrossRef]

30. Sambrook, J.; Russel, D.W. Molecular Cloning: A Laboratory Manual, 3rd ed.; Cold Spring Harbor Laboratory Press: New York, NY, USA, 2001; Volume 49, pp. 895-909.

31. Xie, B.; Zhang, P.; Liu, M.; Zeng, W.; Yang, J.; Liu, H. Deltex1 Polymorphisms Are Associated with Hepatitis B Vaccination Non-Response in Southwest China. PLoS ONE 2016, 11, e0149199. [CrossRef]

32. Madsen, P.; Sørensen, P.; Su, G.; Damgaard, L.H.; Thomsen, H.; Labouriau, R. DMU—A package for analyzing multivariate mixed models. In Proceedings of the World Congress on Genetics Applied to Livestock Production, Belo Horizonte, Brazil, 13-18 August 2006.

33. Liu, K.; Muse, S.V. PowerMarker: An integrated analysis environment for genetic marker analysis. Bioinformatics 2005, 21, 2128-2129. [CrossRef]

34. Zhang, Y.; Zhang, J.; Gong, H.; Cui, L.; Zhang, W.; Ma, J.; Chen, C.; Ai, H.; Xiao, S.; Huang, L.; et al. Genetic correlation of fatty acid composition with growth, carcass, fat deposition and meat quality traits based on GWAS data in six pig populations. Meat Sci. 2019, 150, 47-55. [CrossRef]

35. Wang, L.; Zhao, L.; Zhang, L.; Liu, X.; Hou, X.; Gao, H.; Yan, H.; Zhao, F.; Wang, L. NTN1 Affects Porcine Intramuscular Fat Content by Affecting the Expression of Myogenic Regulatory Factors. Animals 2019, 9, 609. [CrossRef] [PubMed]

36. Liu, X.; Gong, J.; Wang, L.; Hou, X.; Gao, H.; Yan, H.; Zhao, F.; Zhang, L.; Wang, L. Genome-Wide Profiling of the Microrna Transcriptome Regulatory Network to Identify Putative Candidate Genes Associated with Backfat Deposition in Pigs. Animals 2019, 9, 313. [CrossRef] [PubMed]

37. Gol, S.; González-Prendes, R.; Bosch, L.; Tor, M.; Reixach, J.; Pena, R.N.; Estany, J. Linoleic acid metabolic pathway allows for an efficient increase of intramuscular fat content in pigs. J. Anim. Sci. Biotechnol. 2019, 10, 33-41. [CrossRef] [PubMed]

38. Jacyno, E.; Pietruszka, A.; Kawęcka, M.; Biel, W.; Kołodziej-Skalska, A. Phenotypic Correlations of Backfat Thickness with Meatiness Traits, Intramuscular Fat, Longissimus Muscle Cholesterol and Fatty Acid Composition in Pigs. S. Afr. J. Anim. Sci. 2015, 45, 122-128. [CrossRef]

39. Fujii, J.; Otsu, K.; Zorzato, F.; de Leon, S.; Khanna, V.K.; Weiler, J.E.; O’Brien, P.J.; MacLennan, D.H. Identification of a mutation in porcine ryanodine receptor associated with malignant hyperthermia. Science 1991, 253, 448-451. [CrossRef]

40. Veerkamp, J.H.; Maatman, R.G. Cytoplasmic fatty acid-binding proteins: Their structure and genes. Prog. Lipid Res. 1995, 34, 17-52. [CrossRef]

41. Chen, J.N.; Jiang, Y.Z.; Cen, W.M.; Xing, S.H.; Zhu, L.; Tang, G.Q.; Li, M.Z.; Jiang, A.A.; Lou, P.E.; Wen, A.X.; et al. Distribution of H-FABP and ACSL4 gene polymorphisms and their associations with intramuscular fat content and backfat thickness in different pig populations. Genet. Mol. Res. 2014, 13, 6759-6772. [CrossRef] 
42. Serao, N.V.L.; Veroneze, R.; Ribeiro, A.M.F.; Verardo, L.L.; Braccini Neto, J.; Gasparino, E.; Campos, C.F.; Lopes, P.S.; Guimaraes, S.E.F. Candidate gene expression and intramuscular fat content in pigs. J. Anim. Breed. Genet. 2011, 128, 28-34. [CrossRef]

43. Matika, O.; Robledo, D.; Pong-Wong, R.; Bishop, S.C.; Riggio, V.; Finlayson, H.; Lowe, N.R.; Hoste, A.E.; Walling, G.A.; Del-Pozo, J.; et al. Balancing selection at a premature stop mutation in the myostatin gene underlies a recessive leg weakness syndrome in pigs. PLoS Genet. 2019, 15, e1007759. [CrossRef]

44. Lim, K.S.; Lee, K.T.; Park, J.E.; Chung, W.H.; Jang, G.W.; Choi, B.H.; Hong, K.C.; Kim, T.H. Identification of differentially expressed genes in longissimus muscle of pigs with high and low intramuscular fat content using RNA sequencing. Anim. Genet. 2017, 48, 166-174. [CrossRef]

45. Henriquez-Rodriguez, E.; Tor, M.; Pena, R.N.; Estany, J. A polymorphism in the stearoyl-CoA desaturase gene promoter increases monounsaturated fatty acid content in dry-cured ham. Meat Sci. 2015, 106, 38-43. [CrossRef] [PubMed]

46. Li, X.P.; Sangwook, K.; Jungsuck, C.; Yoonmi, L.; Cheolkoo, L.; Bonghwan, C.; Taehun, K.; Yangil, C.; Jongjoo, K.; Kwansuk, K. Investigation of porcine FABP3 and LEPR gene polymorphisms and mRNA expression for variation in intramuscular fat content. Mol. Biol. Rep. 2010, 37, 3931-3939. [CrossRef] [PubMed]

47. Kobayashi, E.; Suzuki, K. Effects of porcine leptin receptor gene polymorphisms on backfat thickness, fat area ratios by image analysis, and serum leptin concentrations in a Duroc purebred population. Anim. Sci. J. 2012, 83, 375-385. [CrossRef]

48. Souza, F.R.P.; Mercadante, M.E.Z.; Fonseca, L.F.S.; Ferreira, L.M.S.; Regatieri, I.C.; Ayres, D.R.; Tonhati, H.; Silva, S.L.; Razook, A.G.; Albuquerque, L.G. Assessment of DGAT1 and LEP gene polymorphisms in three Nelore (Bos indicus) lines selected for growth and their relationship with growth and carcass traits. J. Anim. Sci. 2010, 88, 435-441. [CrossRef] [PubMed]

49. Cepica, S.; Ovilo, C.; Masopust, M.; Knoll, A.; Fernandez, A.; Lopez, A.; Rohrer, G.A.; Nonneman, D. Four genes located on a SSC2 meat quality QTL region are associated with different meat quality traits in Landrace x Chinese-European crossbred population. Anim. Genet. 2012, 43, 333-336. [CrossRef]

50. Holst, L.S.; Langin, D.; Mulder, H.; Laurell, H.; Grober, J.; Bergh, A.; Mohrenweiser, H.W.; Edgren, G.; Holm, C. Molecular Cloning, Genomic Organization, and Expression of a Testicular Isoform of Hormone-Sensitive Lipase. Genomics 1996, 35, 441-447. [CrossRef]

51. Aslan, O.; Hamill, R.M.; Davey, G.; Mcbryan, J.; Mullen, A.M.; Gispert, M.; Sweeney, T. Variation in the IGF2 gene promoter region is associated with intramuscular fat content in porcine skeletal muscle. Mol. Biol. Rep. 2012, 39, 4101-4110. [CrossRef]

52. Uemoto, Y.; Soma, Y.; Sato, S.; Shibata, T.; Kadowaki, H.; Katoh, K.; Kobayashi, E.; Suzuki, K. Mapping QTL for fat area ratios and serum leptin concentrations in a Duroc purebred population. Anim. Sci. J. 2012, 83, 187-193. [CrossRef]

53. Davoli, R.; Braglia, S.; Valastro, V.; Annarratone, C.; Comella, M.; Zambonelli, P.; Nisi, I.; Gallo, M.; Buttazzoni, L.; Russo, V. Analysis of MC4R polymorphism in Italian Large White and Italian Duroc pigs: Association with carcass traits. Meat Sci. 2012, 90, 887-892. [CrossRef]

54. Loos, R.J.F.; Lindgren, C.M.; Li, S.; Wheeler, E.; Zhao, J.H.; Prokopenko, I.; Inouye, M.; Freathy, R.M.; Attwood, A.P.; Beckmann, J.S.; et al. Common variants near MC4R are associated with fat mass, weight and risk of obesity. Nat. Genet. 2008, 40, 768-775. [CrossRef]

55. Liu, J.Y.; Hao, C.L.; Li, W.H.; Lin, J.L.; Wu, F.R.; Bu-gen, S.; Xie, Z.; Li, Q.F. Association of the MC4R gene expression with intramuscular fat content in Hu sheep muscles. J. Nanjing Agric. Univ. 2011, 34, 143-146.

56. Lyadskiy, I.K.; Getya, A.A.; Pochernyaev, K.F. Association of the Asp298Asn polymorphism in the mc4r gene with back fat thickness in pigs of the large white breed. Cytol. Genet. 2011, 45, 106-109. [CrossRef]

(C) 2019 by the authors. Licensee MDPI, Basel, Switzerland. This article is an open access article distributed under the terms and conditions of the Creative Commons Attribution (CC BY) license (http://creativecommons.org/licenses/by/4.0/). 